\title{
MCNP SIMULATION FOR THE CALCULATION OF NEUTRON DOSE RATE OF AmBe AT CUBOID WATER PHANTOM
}

\author{
Simulasi MNCP untuk Perhitungan Laju Dosis Neutron AmBe \\ pada Panthom Air Berbentuk Kubus
}

\author{
Nazaroh', Akbar Rhamadan² dan Rasito Tursinah ${ }^{3}$ \\ 1,2Pusat Teknologi Keselamatan dan Metrologi Radiasi (PTKMR) \\ Jl. Lebak Bulus Raya No.49 Jakarta Selatan \\ ${ }^{3}$ Pusat Sains dan Teknologi Nuklir Terapan (PSTNT) \\ Jl. Taman Sari No,71, Bandung 40132 \\ Badan Tenaga Nuklir Nasional (BATAN) \\ Email: nazaroh_@batan.go.id
}

\begin{abstract}
The neutron dose rate can be determined by a measurement using Radiation Measuring Instrument and by calculation using statistical methods, one of them by MCNP MCNP can simulate the trip of neutron, electron and photon particles in a three-dimensional material. This paper presents a simple MCNP simulation for calculating the neutron dose rate from a point source of $A m B e, 1 \mathrm{MBq}$ activity, the distance $10 \mathrm{~cm}$ from the surface of $1 \mathrm{~cm}^{3} \mathrm{cuboid}$ water phantom, with dead areas at a distance of $15 \mathrm{~cm}$ from the source. The neutron dose rate calculation is performed with a number of 1,000,000 and 10,000,000 neutrons, to see the difference in yield and error. The second exercise, the input of water volume is enlarged to $8 \mathrm{~cm}^{3}, 27$ and $125 \mathrm{~cm}^{3}$, and the third exercise, the input of neutron sources varies in activity 1,3 and $5 \mathrm{MBq}$ and the input distance is varied to $5 ; 10$; and $13 \mathrm{~cm}$ from the phantom. From the simulation, it was obtained that the greater the number of neutrons, the longer the running process but the smaller the error. The neutron dose rate will be smaller if the distance of the neutron source and the volume of water phantom were greater, on the contrary the neutron dose rate will be greater if the neutron source activity is greater and the distance of the neutron source to the phantom and water volume is getting smaller
\end{abstract}

Keywords: simulation, dose, MCNP

\begin{abstract}
Abstrak
Laju Dosis neutron dapat diketahui dengan cara pengukuran, menggunakan Alat Ukur Radiasi (AUR) dan dengan perhitungan, menggunakan metode statistik, salah satunya dengan Metode Monte Carlo N-Particle (MCNP). MCNP dapat menyimulasikan perjalanan partikel neutron, elektron dan foton dalam suatu material tiga dimensi. Makalah ini menyajikan simulasi MCNP sederhana untuk perhitungan laju dosis neutron dari sumber neutron AmBe berbentuk titik, aktivitas $1 \mathrm{MBq}$, berjarak $10 \mathrm{~cm}$ dari permukaan phantom air berbentuk kubus, volume $1 \mathrm{~cm}^{3}$. Dibatasi dengan daerah mati pada jarak $15 \mathrm{~cm}$ dari sumber. Perhitungan laju dosis neutron dilakukan dengan jumlah neutron 1.000.000 dan 10.000.000, untuk melihat perbedaan hasil dan erornya Latihan kedua, inputan volume air diperbesar menjadi $8 \mathrm{~cm}^{3}, 27$ dan $125 \mathrm{~cm}^{3}$, dan latihan ketiga, inputan sumber neutron divariasi aktivitasnya 1, 3 dan 5 MBq dan inputan jaraknya divariasi menjadi 5; 10; dan $13 \mathrm{~cm}$ dari permukaan air. Dari simulasi tersebut diperoleh hasil: semakin besar jumlah neutron, semakin lama proses runningnya tetapi errornya makin kecil. Laju dosis neutron pada phantom akan semakin kecil apabila jarak sumber neutron dengan permukaan phantom air dan volume air makin besar, sebaliknya laju dosis neutron akan semakin besar jika aktivitas sumber neutron makin besar dan jarak sumber neutron dengan permukaan phantom air dan volume air makin kecil
\end{abstract}

Kata kunci: simulasi, MCNP, dosis,

\section{INTRODUCTION}

A calibrated neutron source, AmBe is very useful for calibrating a neutron radiation measuring device. In contrast, free neutrons can be harmful to the body because neutron interactions with body molecules can cause interference with the body's molecules. Free neutrons decay into protons, electrons and antineutrinos. Therefore we need a radiation shielding to be safe from the danger posed by neutrons. (K.W. Geiger, L. Van der Zwan, (1975), (V. Lacoste, et al., 2004), (V. Lacoste, V. et al.,2004), T.Kakavand, et al., (2007), (Isao Murataa*, et al., 2014), (Hector Rene,et al., (2015), V.Gressier, et.al., (2015), Mosegaard, Klaus., and Tarantola, Albert, (1995). 
Neutron dose can be known in two ways, through measurement and calculation. Measurement of neutron doses can be done using a calibrated neutron radiation measuring instrument such as a neutron surveymeter, while the calculation of the neutron dose rate can be done by statistical methods, one of them with Monte Carlo. Monte Carlo is a statistical numerical method by simulating random numbers, it can simulate the trip of neutron, electron and photon particles in a three-dimensional material.

This paper presents a simple simulation of calculating the neutron dose rate using the Monte Carlo Neutron Particle (MCNP). Simulations for doses calculating of point-source of $\mathrm{AmBe}$ neutron, with activity of $1 \mathrm{MBq}, 10 \mathrm{~cm}$ away from the surface of the water phantom, volume $1 \mathrm{~cm}^{3}$, with the number of neutron particles of $1,000,000$ and $10,000,000$, to see the differences in results and errors Second simulation, water volume enlarged to $8 \mathrm{~cm}^{3} ; 27$; and $125 \mathrm{~cm}^{3}$, and the third simulation, the activity of neutrons varies in activity: 1, 3 and $5 \mathrm{MBq}$ and the SDD (source to detector/phantom distance) is varied to: 5 ; 10 ; and $13 \mathrm{~cm}$, with a dead area limit is $15 \mathrm{~cm}$ from the neutron source.

\section{REVIEW}

Among computer programs based on the Monte Carlo method that can be used to simulate neutron particle trips are: Monte Carlo N-Particle (MCNP), Particle and Heavy Ion Transport Code of System (PHITS), Geant4, Fluka, OpenMC, or SuperMC,

The original MCNP program was designed to simulate the journey of neutron, electron and photon particles in a three-dimensional material. (Harvey Gould \& Jan Tobochnik, 1988), This computer program was carried out by the Monte Carlo team at the Los Alamos National Laboratory, USA, (X-5 Monte Carlo Team, 2003. (revised 2008), (V. Lacoste, et al., 2004). C.P. Robert and G. Casella. (2004), (Pelowitz, D.B., 2008), Rasito Tursinah, (2019).

MCNP can also be used to simulate various particles and also ions, namely the release of MCNPX and MCNP6 versions. According to https://id.wikipedia.org swiki, Method_Monte_Carlo (2019), is a computational algorithm to simulate the behavior of various physical and mathematical systems. This method has various applications using an algorithm, which is a step-by-step procedure for automatic calculation, data processing, and reasoning. Because this algorithm requires very complex repetitions and calculations, the Monte Carlo method generally uses computers, and uses various computer simulation techniques. The use of the Monte Carlo method requires a large number of random numbers, and this is made easier with the development of the pseudorandom number generator, which is much faster and more practical than the previous method which uses random number tables for statistical sampling.

MCNP will simulate neutron particles starting from birth then interacting with the material until it ends in the dead area. As shown in Figure 1, suppose a neutron particle from a source interacts with a material. The first interaction (a1) is scattering and then the interaction (a2) results in scattered photons and electrons entering the dead area. The photons formed subsequently interact with the material (b1) producing neutrons and scattered photons which are then absorbed by the material (b2). The neutron formed is then scattered (c1) to then enter the dead area, (Rasito Tursinah, 2019).

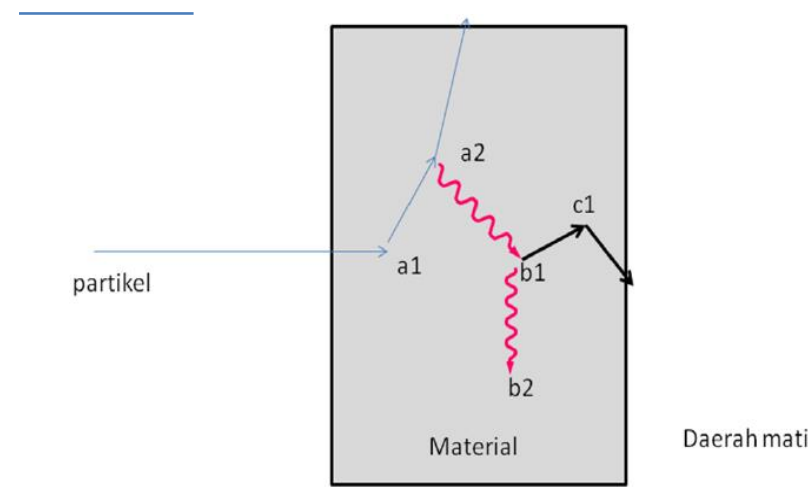

Figure 1. Neutron particles regarding a material (Rasito Tursinah, 2019).

The principle of calculating neutron doses by Analytical Method and Monte Carlo is presented in Figures $2 \mathrm{a}$ and $2 \mathrm{~b}$. In Figure 2a. the calculation of the area under the curve can be calculated by analytical methods, namely by integrating the function and limiting the area to points $a$ and $b$. Whereas the calculation of area $A$ by the Monte Carlo method, in Figure $2 b$, is by multiplying the abscissa length and ordinate and multiplying the number of random numbers that enter the function $f(x)$ divided by the sum of all random numbers in areas $a$ and $b$.

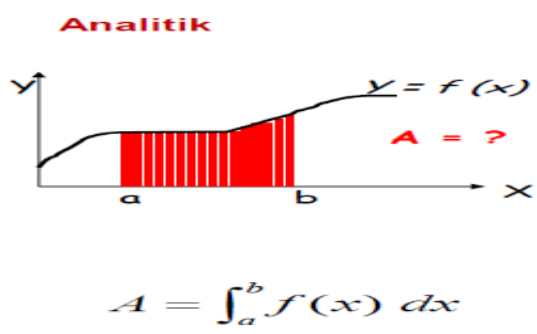


Figure 2a. Analytical Method

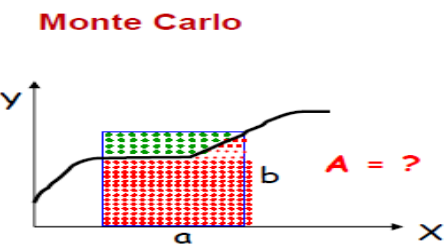

$A=a \cdot b \times \frac{J m l \text { partikel yang masuk area }}{\text { Jml seluruh partikel }}$

Figure 2b. Monte Carlo Method

Equations for calculating doses:

\[ F 6=\int_{E_{i}}^{E 2} d E \int_{t_{1}}^{t 2} d t \emptyset(\vec{r}, E, t) \]
$\begin{array}{ll}\text { Where } & \text { is energy, } \\ \mathrm{E} & \text { is time, and } \\ \mathrm{t} & \text { is a function of position, } \\ \emptyset(\mathrm{r} \rightarrow, \mathrm{E}, \mathrm{t}) \text { scalar flux } \\ \text { energy, and time. }\end{array}$
$\begin{aligned} & \text { The tally of flux conversion to DE/DF dosage is } \\ & \text { used ICRP } 21 \text { (Pelowitz, 2008). }\end{aligned}$

\section{METHOD}

\section{Material and instrument}

Material and instruments used in this experiment were:

- Material and Computer Equipment with 500MB of memory, 11GB hard drive Windows7, 2000. $X P$. Or Vista. Or Linux Extended version

- MCNP software: contains a library of atomic and nuclear cross-section data in continuous energy.

- Main sources of nuclear data:

- Evaluated Nuclear Data File (ENDF),

- Advanced Computational Technology Initiative (ACTI) (Frankle et al., 2002),

- Evaluated Nuclear Data Library (ENDL),

- Evaluated Photon Data Library (EPDL),

- Activation Library (ACTL). Data is formatted into MCNP format using the NJOY program

- Surface card for MCNP input

- Library data for neutron interactions with $\mathrm{H}$

- Tally shape

- MCNP nuclear models and data

\section{MCNP Installation and Running}

- To install MCNP, the files that must be copied to the computer folder are Total Comander, BIN, which contains mcnpx.exe, X11.etc, and the MCNPDATA folder, which contains nuclear data.
- To run it, a connection must be made by adding PATH and DATAPATH to the environment variables in the system properties. PATH and DATAPATH, filled in the name of the location of the stored nuclear data file. For example, PATH $=\%$ PATH\%: D: । MCNPX \ BIN and DATAPATHD: $\backslash$ MCNPX \

\section{MCNP DATA}

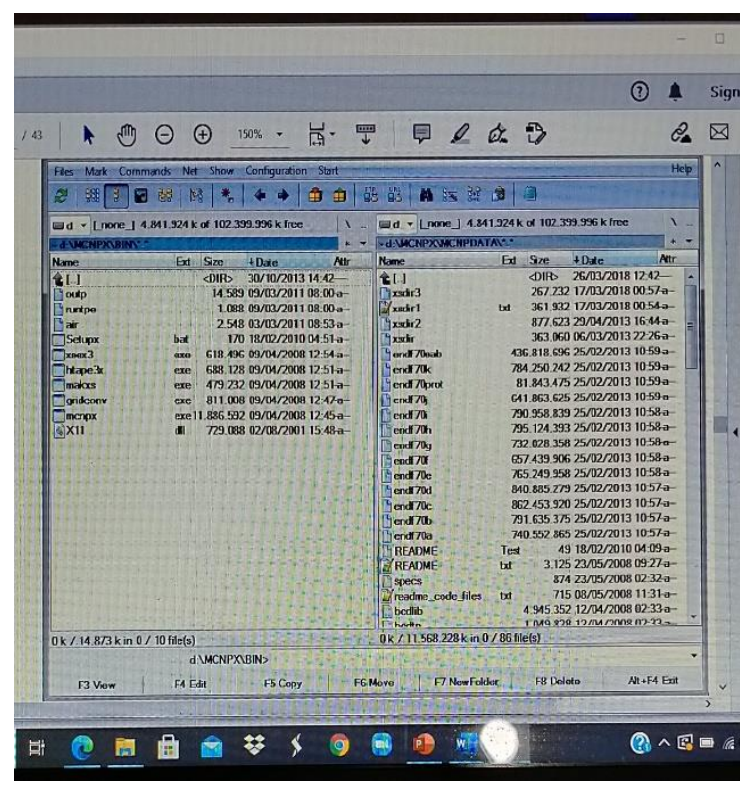

Figure 3 Installing MCNPX on acomputer

To make MCNP input, it can be used notepad. The results of the notepad input file that are saved with the extension. TxT must be changed to extension.FILE uses the promt command. In the Windows operating system, MCNP is run using the command prompt. There is also a practical way with file.bat created so that MCNP can be run easily through the total commander MCNP simulations can provide output in the form of flux, fluence, energy, pulse chopping. Physical quantities of the MCNP output can then be used to obtain quantities such as the rate of exposure to a material. Nuclear data and models used in MCNP are presented in Figure 4. In the MCNP simulation the atom and nuclear cross section data library is used in continuous energy. Especially for neutron interactions, nuclear data is used, because the interactions are specific, where the interaction of neutrons with different isotopes will have very different crosssections. For neutron and photon simulations in this study the ENDF nuclear cross-sectional data was issued by a consortium of research institutes, contractors and universities sponsored by the US 
Department of Energy. To do the simulation using MCNP, there are three stages that are passed, namely making input, running, and interpreting the output.

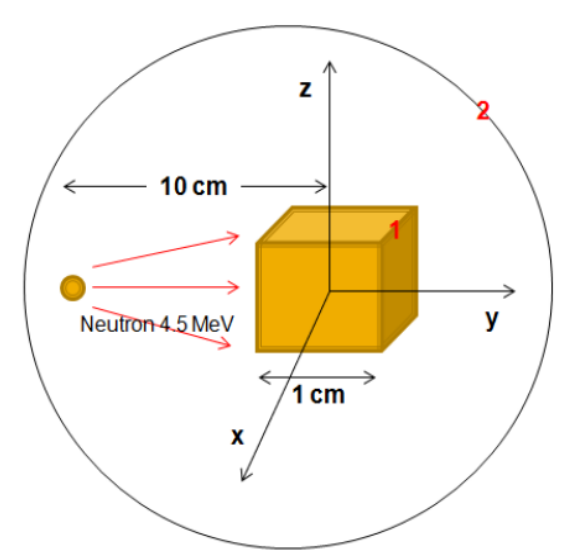

Figure 4. Example of a box shaped cell

In this paper, a simulation was made for an $\mathrm{AmBe}$ neutron point source with an energy of 4.5 MeV( ${ }^{241}$ Am, Recommended data - 2017), 1 $\mathrm{MBq}$ activity, $10 \mathrm{~cm}$ away from a cuboid water phantom, volume $1 \mathrm{~cm}^{3}$, with density $1 \mathrm{~g} / \mathrm{cm}^{3}$. The neutron dose rate that is received by the water phantom is calculated. Figure 4 is an example of a simulation object. Cell 1 is the object to be simulated, cell 2 is an air and cell 3 is a dead area

\section{MCNP input}

Making MCNP input is to fill in the "card". There are three cards in the MCNP input, namely cell card, surface card, and data card. The cell card and the surface card are the geometrical

inputs of the object to be simulated, while the data card is information about the material of the simulated object, the definition of the particle source, and the tally or physical quantity to be calculated.

The radiation dose is the amount of radiation energy absorbed by the material per unit mass, dE/dm. MCNP can be used to calculate doses in the above cases. For the example of Figure 4, if the MCNP is asked to determine the dose in cell 1 then input can be made as follows:

\section{Neutron Dose Simulation}

\begin{tabular}{|c|c|c|c|}
\hline \multicolumn{4}{|l|}{ C cell card } \\
\hline $\begin{array}{l}1 \\
\text { shape water }\end{array}$ & -1.0 & -1 & $\$$ box \\
\hline $2 \quad 2$ & 0.0012 & -2 & \$ air \\
\hline $\begin{array}{ll}3 & 0 \\
\text { area } & \end{array}$ & & 2 & \$ death \\
\hline
\end{tabular}

\begin{tabular}{|c|c|c|c|}
\hline 1 & $\begin{array}{l}\text { rpp } \\
-0.50 .5\end{array}$ & \multicolumn{2}{|c|}{$-0,50.5$} \\
\hline 2 & so $\quad 15$ & & \\
\hline \multicolumn{4}{|c|}{ C data card } \\
\hline $\begin{array}{l}\text { Mode } \\
\text { Imp:n }\end{array}$ & \multicolumn{3}{|l|}{$\mathrm{n}$} \\
\hline $\begin{array}{l}\text { Imp:n } \\
\text { NPS }\end{array}$ & \multicolumn{3}{|l|}{$\begin{array}{l}110 \\
1000000\end{array}$} \\
\hline \multicolumn{4}{|c|}{ C material data } \\
\hline \multirow{2}{*}{$\mathrm{m} 1$} & $1001,60 c$ & 2 & $\$ \mathrm{H}$ \\
\hline & $8016,60 c$ & 1 & $\$ 0$ \\
\hline \multirow[t]{5}{*}{ m2 } & $7014.60 c$ & -0.77798 & $\$ N-14$ \\
\hline & $7015,60 c$ & $-2.89 \mathrm{E}-03$ & $\$ \mathrm{~N}-15$ \\
\hline & 8016.60c & -0.20949 & \$ O-16 \\
\hline & $18000.42 c$ & $-9.64 \mathrm{E}-03$ & $\$ \mathrm{Ar}$ \\
\hline & definition & & \\
\hline sdef & $\mathrm{erg}=4.5$ & pos $=0$ & -100 \\
\hline tally & \multicolumn{3}{|l|}{ par $=n$} \\
\hline $6: n$ & \multicolumn{3}{|l|}{1} \\
\hline & \multicolumn{3}{|l|}{$1 \mathrm{E}+6$} \\
\hline
\end{tabular}

\section{MCNP output}

The MCNP output is in a MeV/g/s unit. and the unit dose rate is Joule $/ \mathrm{kg} / \mathrm{s}$ or Gy/s. for that, from F6 output must be multiplied by 1.6.10 10 .

\section{RESULTS AND DISCUSSION}

Figure $5 \mathrm{a}$. presented the results of neutron dose rate of $\mathrm{AmBe}$ on the water phantom using MCNP simulatiom, where the neutron source with activities 1,3 and $5 \mathrm{MBq}$, are alternately placed in front of the water phantom with a distance of 10 $\mathrm{cm}$. The neutron dose rate obtained at a distance of $10 \mathrm{~cm}$ is greater than the dose rate at a distance of $13 \mathrm{~cm}$. It can be concluded that the greater the distance of the source to phantom / to humans, the smaller the dose rate, so that the dose received within a certain time, $t$, will be smaller. From this case, it was concluded that the principle of radiation protection must pay attention to the distance factor. The further away from the radiation source, the safer will be.

The neutron dose rate of $\mathrm{AmBe}$ in water phantom with activity of neutron: 1 ; 3 and $5 \mathrm{MBq}$

at SDD $10 \mathrm{~cm}$ away from phantom

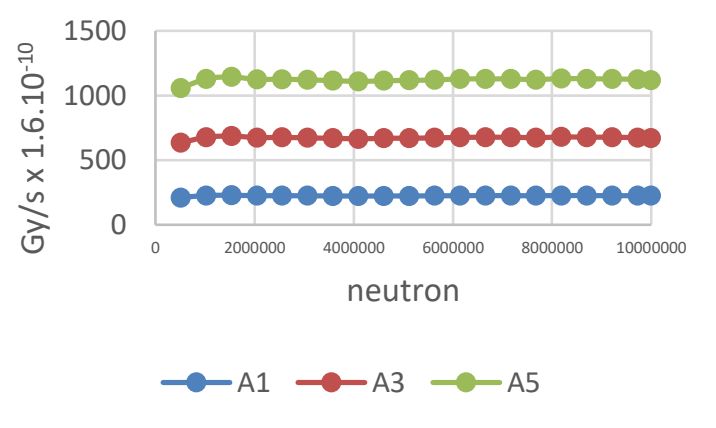


Figure $5 \mathrm{a}$. Neutron dose rate calculations of $\mathrm{AmBe}$ in water phantom. The neutron activity : 1, 3 and $5 \mathrm{MBq}$, at SDD : $10 \mathrm{~cm}$ from phantom.

Note: The unit of dosage rate is Joule/kg/s or Gy/s. From output F6 must be multiplied by 1.6.10-10.

Figure 5b. presented the simulation results of $\mathrm{AmBe}$ neutron dose rate on a cuboid water phantom, at $1 \mathrm{~cm}^{3}$ in volume. The neutron source activity: 1,3 and $5 \mathrm{MBq}$. The calculation of the dose rate is carried out with the number of neutrons $10,000,000$. It can be seen that for the neutron source with the activity of $5 \mathrm{MBq}$ (green dot), it produces a greater dose rate than the neutron source with activity 3 and $1 \mathrm{MBq}$ (red dot and blue dot).

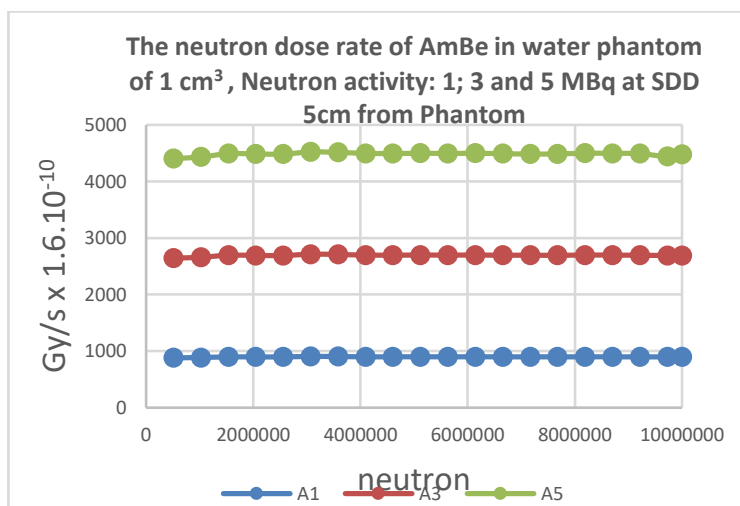

Figure $5 b$. Neutron dose rates of $A m B e$ in water phantom, at SDD $5 \mathrm{~cm}$ from the phantom.

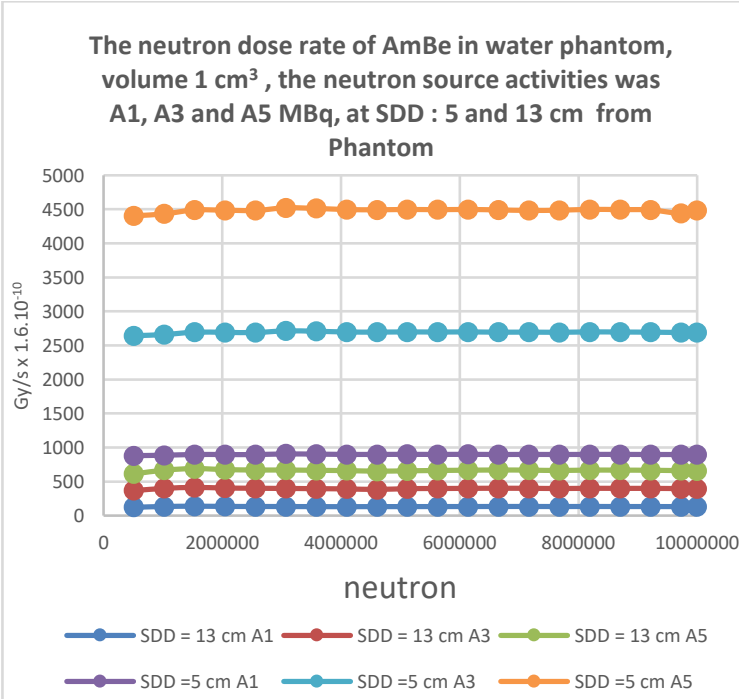

Figure 6. The neutron dose rate of $\mathrm{AmBe}$ in water phantom, at volume $1 \mathrm{~cm}^{3}$

The neutron source activities was $\mathrm{A} 1, \mathrm{~A} 3$ and $\mathrm{A} 5 \mathrm{MBq}$, at SDD: 5 and $13 \mathrm{~cm}$ from Phantom

In Figure 6, it was presented the calculation of the neutron dose rate of $\mathrm{AmBe}$, with activity $\mathrm{A} 1$; $\mathrm{A} 3$ and $\mathrm{A} 5 \mathrm{MBq}$, received by cuboidal water phantoms, volume $1 \mathrm{~cm}^{3}$, with 10,000 neutrons. It can be seen that at SDD $13 \mathrm{~cm}$ (neutron source activity $\mathrm{A} 1, \mathrm{~A} 3$ and $\mathrm{A} 5 \mathrm{MBq}$ ), the neutron dose rate is smaller than the neutron dose rate at SDD $5 \mathrm{~cm}$. The neutron dose rate is getting smaller because of the distance factor. This is an evidence that the radiation protection system can be done by adjusting the distance.

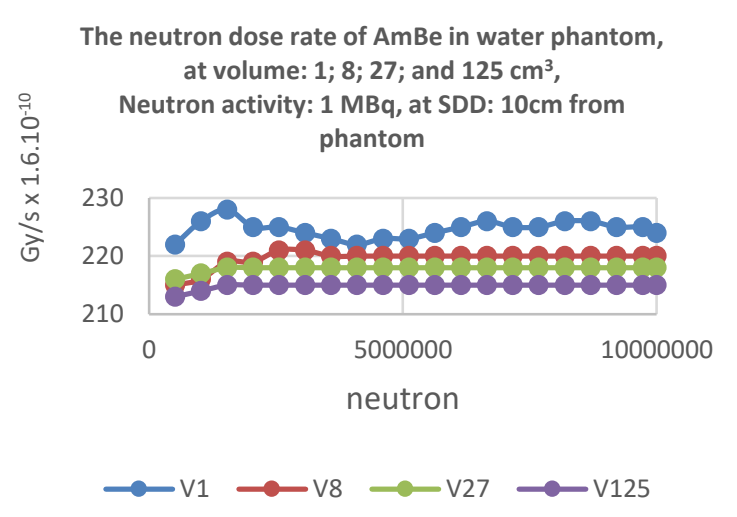

Figure $7 \mathrm{a}$. The neutron dose rate of $\mathrm{AmBe}$ in water phantom, at volume : $1 ; 8 ; 27$; and $125 \mathrm{~cm}^{3}$. The neutron activity was $1 \mathrm{MBq}$, at SDD: $10 \mathrm{~cm}$ from phantom

In Figure 7a, it was presented the calculation of neutron dose rate of $\mathrm{AmBe}$, with activity $A 1$; which is received by a cuboid water phantom, volume 1; 8; 27; and $125 \mathrm{~cm}^{3}$, with 10,000 neutrons. It was seen that at $\mathrm{A} 1 \mathrm{MBq}$, the smallest neutron dose rate was obtained in phantom water volume $\mathrm{V} 125 \mathrm{~cm}^{3}$ compared to the neutron dose rate at V27; V8; and V1 $\mathrm{cm}^{3}$. The neutron dose rate was getting smaller because of the phantom volume factor. This is an evidence that the radiation protection system on neutrons can be done by adjusting the volume of water phantom.

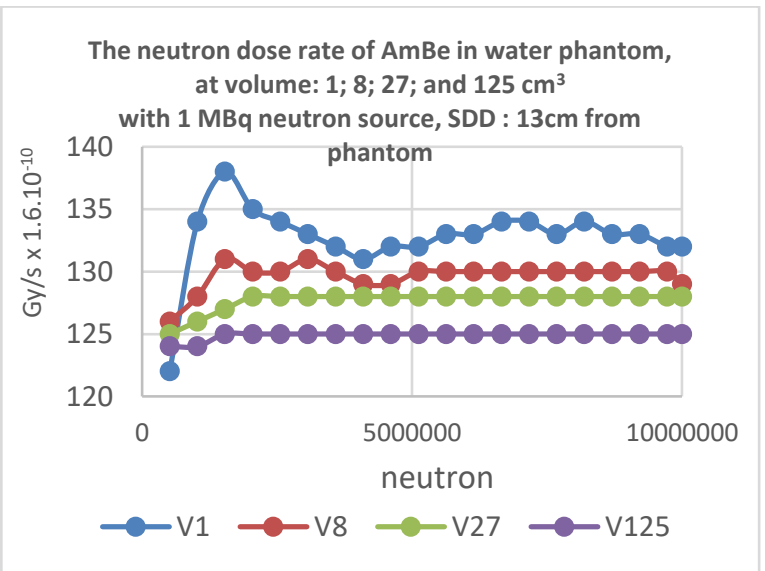


Figure 7b. The neutron dose rate of $\mathrm{AmBe}$ in water phantom (volume: 8; 27 ; and $125 \mathrm{~cm}^{3}$ )

Neutron source activity: $1 \mathrm{MBq}$, at SDD $13 \mathrm{~cm}$ from phantom

In Figure 7b, it was presented the calculation of neutron dose rate of $\mathrm{AmBe}, 1 \mathrm{MBq}$ activity, received by a cuboid water phantom, volume : $1 \mathrm{~cm}^{3}, 8 ; 27$; and $125 \mathrm{~cm}^{3}$. with a number of $10,000,000$ neutrons. It appears that the greater the volume of water phantom (red dot) and the further the distance of the neutron source to the phantom of water, the smaller the neutron dose rate because it was absorbed by the water volume and distance factor. This was proven that the radiation protection system can be done by adjusting the distance and thickness of the shielding / water.

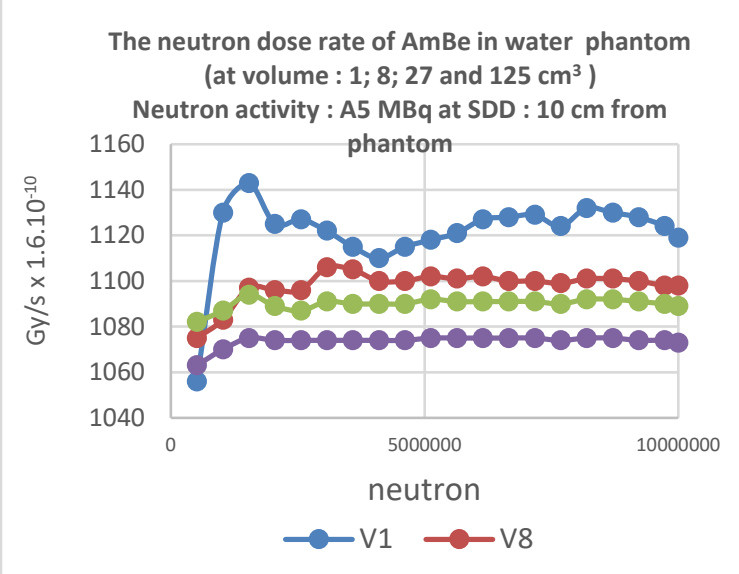

Figure 7c. The neutron dose rate of $\mathrm{AmBe}$ in water phantom (at volume : $1 ; 8 ; 27$ and $125 \mathrm{~cm}^{3}$ )

Neutron Activity : A5 MBq at SDD: $10 \mathrm{~cm}$ from phantom

In Figure 7c, it was presented the calculation of the dose rate of $\mathrm{AmBe}, \mathrm{A} 5 \mathrm{MBq}$ which was received by a cuboid water phantom, at volume: $1 ; 8 ; 27$; and $125 \mathrm{~cm}^{3}$, with 10,000,000 neutrons. It can be seen that at the neutron activity $\mathrm{A} 5 \mathrm{MBq}$, it was obtained that a neutron dose rate greater than $\mathrm{A} 1 \mathrm{MBq}$, but the smallest dose rate in water phantom at volume $\mathrm{V} 125 \mathrm{~cm}^{3}$ compared with the neutron dose rate at V27; V8; and $\mathrm{V} 1 \mathrm{~cm}^{3}$. The neutron dose rate is getting smaller because of the phantom volume factor/absorption and neutron source activity. It was proven that the radiation protection system on neutrons can be done by adjusting the thickness of the shielding / volume of water and source activity.

\section{CONCLUSION}

From a simple simulation of calculating the neutron dose rate with MCNP, the results show that: the greater the number of neutrons and the more complicated the parameters processed, the longer the running process but the error was smaller. The neutron dose rate will be smaller if the distance between the neutron source and the material and the volume of material is greater, on the other hand, the neutron dose rate will be greater if the neutron source activity is greater and the distance between the neutron source and material is smaller.

This MCNP can be applied for calculation of doses in humans but there are complexities in modeling the geometry of the human body.

\section{ACKNOWLEDGMENT}

'The author would like to thank PTKMR BATAN for conducting the MCNP simulation training, in particular thanks to Mr. Rasito Tursinah, M.Sc, as a lecturer and Mr. Ir. BY Eko Budi Jumpeno, MSi, as the Chair of the Organizers

\section{REFERENCES}

${ }^{241} \mathrm{Am}$, Recommended data - LNHB (2017) updated: $20^{\text {th }}$ October 2017

Bernd A. Berg, (2004), Markov Chain Monte Carlo Simulations and Their Statistical Analysis (With Web-Based Fortran Code), World Scientific, ISBN 981-238-935-0.

C.J. Werner1, J.S. Bull1, C.J. Solomon1, F.B. Brown1, G.W. McKinney2, M.E. Rising1, D.A. Dixon1, R.L. Martz1, H.G. Hughes1, L.J. Cox1, A. J. Zukaitis1, J.C. Armstrong1, R. A. Forster1, L. Casswell1, (2018), Mcnp Version 6.2 Release Notes, 46 Instrumentation Related To Nuclear Science And TechnoLogy; Mcnp, La-Ur-18-20808, Los Alamos National Lab. (LANL), Los Alamos, NM (United States),

CJ Werner, JS Bull, CJ Solomon, FB Brown, GW McKinney, ME Rising, (2018), MCNP version 6.2 release notes ...Los Alamos National Lab.(LANL), Los Alamos, NM (United States)

C.P. Robert and G. Casella. (2004), "Monte Carlo Statistical Methods" (second edition). New York: Springer-Verlag, ISBN 0-387-212396.

Hector Rene Vega-Carrillo, Segundo Agustín Martinez-Ovalle, (2015), Neutron spectra and dosimetric features of Isotopic neutron sources: A review, Unidad Académica de Estudios Nucleares de la UAZ C. Cipres 10, Fracc. La Peñuela. 98068 Zacatecas, Zac. Mexico, ISSSD, E-mail: fermineutron@yahoo.com 
Isao Murataa*, lehito Tsudaa, Ryotaro Nakamuraa, Shoko Nakayamab, Masao Matsumotob and Hiroyuki Miyamaruc, (2014), Neutron and gamma-ray sourceterm characterization of $A m B e$ sources in Osaka University, Progress in Nuclear Science and Technology Volume $4 \mathrm{pp}$. 345-348, Atomic Energy Society of Japan. DOI: $10.15669 /$ pnst.4.345.

https://id.wikipedia.org ıwiki, Method_MonteCarlo. (2019)

Mohr, P.J.; Taylor, B.N. and Newell, D.B. (2014), "The 2014 CODATA Recommended Values of the Fundamental Physical Constants" (Web Version 7.0). The database was developed by J. Baker, M. Douma, and S. Kotochigova. (2014). National Institute of Standards and Technology, Gaithersburg, Maryland 20899.

MW Schraad, JD Regele, CJ Werner, RC Rael, (2019) The Computational Physics Division at Los Alamos National Laboratory, Los Alamos National Lab.(LANL), Los Alamos, NM (United States)

Pelowitz, D.B., (2008), "MCNPX User's Manual Version 2.6.0", LANL, USA

PIMAL: (2017), Phantom with Moving Arms and Legs Version 4.1.0NUREG/CR-7243, USNRC.

Rasito Tursinah, (2019) Simulasi Monte Carlo untuk Dosimetri Neutron, Pelatihan Simulasi MCNP, PTKMR-BATAN, 19-20 Desember 2019T.Kakavand, H.Ghafourian, M.Haji-Shafeieha, (2007),
Technical innovation Designing an Am-Be miniature neutron source. Department of Physics, Zanjan University, Zanjan, Iran. Atomic Energy Organization of Iran, Tehran, Iran, J. Radiat. Res; 5 (1): 41-4 44.

V.Gressier, L. Van Ryckeghem, B. Asselineau, R. Babut, J.F. Guerre-Chaley, V. Lacoste, L.Lebreton, A. Martin, H. Muller, G. Pelcot, J.L. Pochat, (2018), Recent developments in neutron metrology at the Institute for Radiological Protection and Nuclear Safety (IRSN) CCRI(III)/05-18.

V. Lacoste, V. Gressier, H. Muller and L. Lebreton (2004), Characterisation of the IRSN graphite moderated AmericiumBeryllium neutron field, Radiation Protection Dosimetry 110 (1-4), p 135-139.

V. Lacoste, V. Gressier, (2004), Monte Carlo simulation of the IRSN CANEL/T400 realistic mixed neutron-photon radiation field, Radiation Protection Dosimetry,110 (1-4), p $123-127$.

V. Lacoste, V. Gressier, (2005), Monte-Carlo simulation of the operational quantities at the realistic mixed neutron-photon radiation fields CANEL and SIGMA, European workshop on individual monitoring of ionising radiation, Vienna / Austria (to be published in RPD).

X-5 Monte Carlo Team, (revised 2008), MCNP-A General Monte Carlo N-Particle Transport Code, Version 5 - Vol. I: Overview and Theory, Los Alamos National Laboratory report LA-UR-03, 
